\title{
Variability in Alternaria alternata Causing Potato Brown Spot under Different Hydrogen Ion Concentration
}

\author{
Shrishti Lingwal* and Asha Sinha
}

Department of Mycology and Plant Pathology, Institute of Agricultural Sciences, Banaras Hindu University, Varanasi, Uttar Pradesh-221005, India

*Corresponding author

\section{A B S T R A C T}

\section{Keywords \\ Alternaria \\ alternata, Brown spot, $\mathrm{pH}$, Potato, Uttar Pradesh \\ Article Info \\ Accepted: \\ 10 March 2018 \\ Available Online: \\ 10 April 2018}

\begin{abstract}
A total of thirty isolates of A. alternata were collected from eastern Uttar Pradesh and parts of Bihar, India. All thirty isolates were evaluated for their growth and rate of growth at three different $\mathrm{H}^{+}$ion concentrations $(\mathrm{pH})$ viz. four, six and eight in PDA medium. Radial growth for all of the isolates of A. alternata was also found significantly maximum at $\mathrm{pH} 6$ followed by $\mathrm{pH} 8$ and $\mathrm{pH} 4$. Also, it was noted that none of the isolate had statistically similar growth in different $\mathrm{pH}$ range. At $\mathrm{pH} 4$, range of radial growth for thirty isolates ranged between 28.50 to $38.00 \mathrm{~mm}$, at $\mathrm{pH} 6,90.00 \mathrm{~mm}$ to $66.00 \mathrm{~mm}$ whereas for $\mathrm{pH}$ 8 growth of $A$. alternata isolates ranged between 49.50 and $58.00 \mathrm{~mm}$. Likewise, rate of growth for all of the isolates of A. alternata was also found significantly maximum at $\mathrm{pH} 6$ followed by $\mathrm{pH} 8$ and $\mathrm{pH} 4$. None but one of the isolate had statistically similar rate of growth in different $\mathrm{pH}$ range i.e. Mohobbatpur had $4.67 \mathrm{~mm}$ and $4.58 \mathrm{~mm}$ rate of growth at $\mathrm{pH} 8$ and 4 respectively which were found statistically at par each other.
\end{abstract}

\section{Introduction}

The genus Alternaria was established in 1817 with Alternaria alternata (originally Alternaria tenuis) as the type-isolate (Thomma, 2003). The genus Alternaria is an important pathogen on standing crop in field and it poses a serious threat after harvest as well. By virtue of mycotoxin producing capability, it is also seen as a contaminant in food items. Droby et al., (1984) for the first time reported pathogenicity of Alternaria alternata in potato. This report was followed by several other reports from all over the world (Boiteux and Reifschneider, 1994; Thomma, 2003; Van der Waals et al., 2011 and Shahid et al., 2018). Potato is one of the major crops of India and Uttar Pradesh in particular, which stands first in potato production within India (URL 1).

The potato crop is known to be affected by several diseases among them, early blight caused by Alternaria solani and late blight caused by Phytophthora infestans cause huge economic losses (Singh and Rana, 2014).

Recently, potato crop in eastern Uttar Pradesh has been seen with new symptoms similar to brown spot disease reported from other parts of the globe. The involvement of the $A$. alternate with the disease was confirmed (data 
unpublished). Present study was conducted to understand the variability in the pathogenic isolates.

\section{Materials and Methods}

Present investigations on Alternaria alternata causing brown spot of potato were carried out in at Department of Mycology and Plant Pathology, Institute of Agriculture Sciences, BHU- Varanasi, Uttar Pradesh.

\section{Collection of samples}

Samples were collected from potato growing districts of Eastern Uttar Pradesh viz., Sultanpur, Faizabad, Amethi, Jaunpur, Azamgarh, Mau, Ghazipur, Varanasi, Bhadoi, Mirzapur Chandauli, Raebarely, Kanpur along with Dumraon and Nalanda areas of Bihar. A code was assigned for ease of handling to each isolate. Details of place of collection of isolates and code assigned are given in Table 1.

\section{Isolation and maintenance of isolates}

Leaf sample with typical spot symptom were taken from the collected samples and washed under tap water to remove dust particle. Under aseptic condition of laminar air flow small bits of sample portion showing symptom were cut with the help of sterilized blade and surface sterilized in $0.1 \%$ sodium hypochlorite for 30 seconds. These bits were then washed thrice in sterilised distilled water for 15 seconds and placed in sterilized blotting paper to remove excess moisture. These bits were placed aseptically in Petri dish containing solidified Potato Dextrose Agar (PDA) medium. These inoculated plates were placed in BOD incubator for growth of the organism at $26 \pm 2{ }^{\circ} \mathrm{C}$. On the basis of morphology of conidia and conidial chains the pathogen was identified as A. alternata and purified by single spore isolation method.

\section{Identification of the pathogen}

The pathogen was identified on the basis of its pathogenicity test, cultural and morphological characteristics. Slides from cultured mycelia were prepared on lacto phenol and observed under compound microscope.

Identification of the pathogen was done on the basis of cultural and morphological grounds as described by various authors (Gilman, 1975; Subramanian, 1971; Barnett and Bany, 1972; Ellis, 1971; Droby et al., 1984; Ellis and Gibson, 1975 and Van der Waals, 2011).

\section{Evaluation of effect of different pH}

A total three $\mathrm{pH}$ level i.e. 4,6 and 8 were selected to study the variability among different isolates in different $\mathrm{H}^{+}$ion concentrates. The $\mathrm{pH}$ of potato dextrose medium was adjusted to three different levels mentioned above with the help of digital $\mathrm{pH}$ meter using $\mathrm{NaOH}(0.1 \mathrm{~N})$ and $\mathrm{HCl}(0.1 \mathrm{~N})$ solution. The $\mathrm{pH}$ was also recorded by using $\mathrm{pH}$ strips before autoclaving for keeping the $\mathrm{pH}$ constant. The sterilized media of different $\mathrm{pH}$ levels were poured in the sterilized Petri plates in about $20 \mathrm{ml}$ quantities and allowed to solidify. After solidification of the medium each plate was centrally inoculated with $10 \mathrm{~mm}$ mycelial disc taken from the actively growing tips of eight days old culture with the help of a sterilized cork borer. Each treatment was replicated twice. Inoculated Petri plates were incubated at $26+1^{\circ} \mathrm{C}$. The observations on radial mycelial growth or colony diameter $(\mathrm{mm})$ on each $\mathrm{pH}$ level were recorded at 48 hrs interval and continued till eight days after inoculation.

The growth rate of the fungus on each medium was calculated as follows.

$$
G R=\frac{S_{x+1}-S_{x}}{T_{x+1}-T_{x}}
$$


Where, $\mathrm{G} \mathrm{R}=$ Growth rate $\left(\mathrm{mm} \mathrm{hr}^{-1}\right), \mathrm{S}=$ Colony diameter $(\mathrm{mm}), \mathrm{T}=$ Time (days.)

\section{Statistical analysis}

The data recorded during course of investigations were subjected to statistical analysis using STPR software.The significance of treatment difference was tested bt F- test on the basis of null hypothesis. The appropriate standard error (S.Em \pm ) was computed in each case. Coefficient of variance per cent was also worked out for all the characters

\section{Results and Discussion}

Based on the morphological and cultural characteristics all the thirty fungal isolates were identified as A. alternata on the basis of its cultural and morphological structures observed under compound microscope. Identity was confirmed by literature (Gilman, 1975; Subramanian, 1971; Barnett and Bany, 1972). Data pertaining radial growth and rate of growth of the test organism in five different $\mathrm{pH}$ viz., 4, 5 and 6 is presented in table 2 and 3 respectively.

\section{Radial growth $A$. alternataisolates at different $\mathrm{H}^{+}$ion concentration $(\mathrm{pH})$}

At $\mathrm{pH}$ four no isolate grew more than 38.00mmat eight days post incubation (DPI). Significantly maximum growth was observed in isolate Mohobbatpur (38.00mm) which was found statistically at par with Keshavpur (37.50mm), Raipur (37.00mm), Jafrabad (37.00mm), Ugapur $(36.50 \mathrm{~mm})$ and Dumraon (36.50mm). Minimum radial growth was observed in isolate Chunar $(28.50 \mathrm{~mm})$ followed by Jansa $(29.50 \mathrm{~mm})$, Kandhiya, Chirrayyakot, Makdumpur, Pindra each with $31.00 \mathrm{~mm}$ radial growth. At $\mathrm{pH}$ six, a total of five isolates viz., Pindra, Jamalpur (JJ), Bhikharipur, Raibarely, Kanpur-C, were found to grow $90.00 \mathrm{~mm}$ radial growth. Chunar $(88.50 \mathrm{~mm})$ was found statistically at par maximum. Minimum radial growth at $\mathrm{pH}$ six was found in isolate Sidhona $(66.00 \mathrm{~mm})$ followed by Mohommadabad $(67.50 \mathrm{~mm})$, Kanpur-M (68.50mm) and Raipur $(68.50 \mathrm{~mm})$ found at par each other. Similarly, at $\mathrm{pH}$ eight, radial growth of $A$. alternata isolates varied from $58.00 \mathrm{~mm}$ to $49.50 \mathrm{~mm}$. significantly maximum radial growth was found in Keshavpur (58.00mm) followed Vindhyanchal $(57.00 \mathrm{~mm}), \quad$ Chirrayyakot $\quad(56.50 \mathrm{~mm})$, Raibarely (56.50mm), BHU $(56.00 \mathrm{~mm})$, Mohommadabad $\quad(56.00 \mathrm{~mm}), \quad$ Pindra $(55.50 \mathrm{~mm})$, Ugapur $(55.50 \mathrm{~mm})$, Sidhona $(55.50 \mathrm{~mm})$, Kanpur-M $(55.50 \mathrm{~mm})$, Nalanda $(55.50 \mathrm{~mm})$ and Bharpura-2 $(55.00 \mathrm{~mm})$, were found at par each other. Minimum radial growth was present in isolate Kandhiya $(49.50 \mathrm{~mm})$ which was found at par Bharpura1(50.00mm), Mohobbatpur (51.00), Rajepur $(51.50 \mathrm{~mm})$ and Kanpur-C (51.00mm).

\section{Rate of growth $A$. alternate isolates at different $\mathrm{H}^{+}$ion concentration (pH)}

At $\mathrm{pH}$ four Keshavpur (4.92mm) was observed to have maximum rate of growth and was found at par with Raipur $(4.75 \mathrm{~mm})$, Rajepur $(4.67 \mathrm{~mm})$, Mohobbatpur $(4.58 \mathrm{~mm})$, Jamalpur $\quad(4.50 \mathrm{~mm}), \quad$ Mohommadabad $(4.42 \mathrm{~mm})$ and Vindhyanchal $(4.42 \mathrm{~mm})$.

Minimum rate of radial growth was observed in isolate Bhikharipur $(3.08 \mathrm{~mm})$ followed by Pindra (3.5mm), Chunar (3.5mm), Rajpur-1 (3.67mm), Rajpur-2 (3.83mm), Kandhiya (3.92mm), Raibarely (3.92mm), Dumraon (3.92) and Jafrabad $(4.00 \mathrm{~mm})$ which were found statistically at par each other. At $\mathrm{pH}$ six significantly maximum rate of growth was observed in Raibarely (12.92mm) followed by Rastamau (11.08mm), Vindhyanchal (10.92mm), Nalanda (10.92mm) and KanpurC $(10.75 \mathrm{~mm})$ which were found at par each other. 
Table.1 Isolates of A. alternata their place of collection and isolate codes

\begin{tabular}{|c|c|c|c|c|}
\hline $\begin{array}{l}\text { S. } \\
\text { No. }\end{array}$ & Place & District & $\begin{array}{l}\text { Isolate } \\
\text { code }\end{array}$ & $\begin{array}{l}\text { Morphological identity } \\
\text { of pathogenic isolates }\end{array}$ \\
\hline 1. & Jansa & Varanasi & JV & Alternaria alternata \\
\hline 2. & $\mathrm{BHU}$ & Varanasi & $\mathrm{BV}$ & Alternaria alternata \\
\hline 3. & Pindra & Varanasi & PV & Alternaria alternata \\
\hline 4. & Leva & Chandauli & $\mathrm{LC}$ & Alternaria alternata \\
\hline 5. & Raipur & Ghazipur & RG & Alternaria alternata \\
\hline 6. & Makdumpur & Ghazipur & MG & Alternaria alternata \\
\hline 7. & Mohommadabad & Mau & $\mathrm{MMu}$ & Alternaria alternata \\
\hline 8. & Chirrayyakot & Mau & $\mathrm{CMu}$ & Alternaria alternata \\
\hline 9. & Rajepur & Azamgarh & RA & Alternaria alternata \\
\hline 10. & Mohobbatpur & Azamgarh & MA & Alternaria alternata \\
\hline 11. & Jamalpur & Jaunpur & $\mathrm{JJ}$ & Alternaria alternata \\
\hline 12. & Keshavpur & Jaunpur & $\mathrm{KJ}$ & Alternaria alternata \\
\hline 13. & Jafrabad & Jaunpur & JFJ & Alternaria alternata \\
\hline 14. & Kandhiya & Bhadoi & $\mathrm{KB}$ & Alternaria alternata \\
\hline 15. & Bhikharipur & Bhadoi & $\mathrm{BB}$ & Alternaria alternata \\
\hline 16. & Ugapur & Bhadoi & UB & Alternaria alternata \\
\hline 17. & Vindhyanchal & Mirzapur & VM & Alternaria alternata \\
\hline 18. & Rajpur-1 & Mirzapur & $\mathrm{RM}-1$ & Alternaria alternata \\
\hline 19. & Rajpur-2 & Mirzapur & $\mathrm{RM}-2$ & Alternaria alternata \\
\hline 20. & Bharpura-1 & Mirzapur & BM-1 & Alternaria alternata \\
\hline 21. & Bharpura-2 & Mirzapur & $\mathrm{BM}-2$ & Alternaria alternata \\
\hline 22. & Chunar & Mirzapur & $\mathrm{CM}$ & Alternaria alternata \\
\hline 23. & Jamalpur & Mirzapur & $\mathrm{JM}$ & Alternaria alternata \\
\hline 24. & Raibareli & Raibarely & RR & Alternaria alternata \\
\hline 25. & Rastamau & Amethi & RMA & Alternaria alternata \\
\hline 26. & Sidhona & Faizabad & $\mathrm{SF}$ & Alternaria alternata \\
\hline 27. & Kanpur-M & Kanpur & KK-1 & Alternaria alternata \\
\hline 28. & Kanpur-C & Kanpur & $\mathrm{KK}-2$ & Alternaria alternata \\
\hline 29. & Nalanda & Nalanda & NNB & Alternaria alternata \\
\hline 30. & Dumraon & Buxar & $\mathrm{DBB}$ & Alternaria alternata \\
\hline
\end{tabular}


Table.2 Variability in growth of thirty isolates of Alternaria alternata at different $\mathrm{H}^{+}$ion concentration $(\mathrm{pH})$

\begin{tabular}{|c|c|c|c|c|}
\hline \multirow{2}{*}{$\begin{array}{l}\text { S. } \\
\text { No. }\end{array}$} & \multirow[t]{2}{*}{ Isolate } & \multicolumn{3}{|c|}{$\mathrm{pH}$} \\
\hline & & 4 & 6 & 8 \\
\hline 1. & Jansa & 29.50 & 86.00 & 52.50 \\
\hline 2. & $\mathrm{BHU}$ & 33.50 & 80.50 & 56.00 \\
\hline 3. & Pindra & 31.00 & 90.00 & 55.50 \\
\hline 4. & Leva & 33.50 & 81.50 & 52.00 \\
\hline 5. & Raipur & 37.00 & 68.50 & 53.00 \\
\hline 6. & Makdumpur & 31.00 & 70.00 & 54.50 \\
\hline 7. & Mohommadabad & 32.50 & 67.50 & 56.00 \\
\hline 8. & Chirrayyakot & 31.00 & 80.50 & 56.50 \\
\hline 9. & Rajepur & 34.00 & 79.00 & 51.50 \\
\hline 10. & Mohobbatpur & 38.00 & 80.00 & 51.00 \\
\hline 11. & Jamalpur & 34.50 & 90.00 & 54.00 \\
\hline 12. & Keshavpur & 37.50 & 82.50 & 58.00 \\
\hline 13. & Jafrabad & 37.00 & 81.00 & 54.50 \\
\hline 14. & Kandhiya & 31.00 & 78.50 & 49.50 \\
\hline 15. & Bhikharipur & 32.00 & 90.00 & 53.50 \\
\hline 16. & Ugapur & 36.50 & 70.00 & 55.50 \\
\hline 17. & Vindhyanchal & 33.50 & 80.50 & 57.00 \\
\hline 18. & Rajpur-1 & 33.50 & 82.50 & 53.00 \\
\hline 19. & Rajpur-2 & 33.00 & 83.50 & 52.00 \\
\hline 20. & Bharpura-1 & 33.50 & 76.00 & 50.00 \\
\hline 21. & Bharpura-2 & 33.50 & 79.50 & 55.00 \\
\hline 22. & Chunar & 28.50 & 88.50 & 53.00 \\
\hline 23. & Jamalpur & 33.50 & 83.50 & 53.00 \\
\hline 24. & Raibarely & 32.50 & 90.00 & 56.50 \\
\hline 25. & Rastamau & 31.50 & 80.00 & 53.50 \\
\hline 26. & Sidhona & 32.50 & 66.00 & 55.50 \\
\hline 27. & Kanpur-M & 34.00 & 68.50 & 55.50 \\
\hline 28. & Kanpur-C & 32.50 & 90.00 & 51.50 \\
\hline 29. & Nalanda & 34.50 & 85.00 & 55.50 \\
\hline 30. & Dumraon & 36.50 & 69.00 & 53.00 \\
\hline & & Isolate (I) & pH (p) & $\mathbf{I} \times \mathbf{p}$ \\
\hline SEn & & 0.92 & 0.29 & 1.60 \\
\hline $\mathbf{C D}$ & & 3.45 & 1.09 & 5.98 \\
\hline $\mathrm{CV}$ & & 4.08 & & \\
\hline
\end{tabular}


Table.3 Variability in rate of growth of thirty isolates of Alternaria alternata at different $\mathrm{H}^{+}$ion concentration $(\mathrm{pH})$

\begin{tabular}{|c|c|c|c|c|}
\hline \multirow{2}{*}{$\begin{array}{l}\text { S. } \\
\text { No. }\end{array}$} & \multirow[t]{2}{*}{ Isolate } & \multicolumn{3}{|c|}{ pH } \\
\hline & & 4 & 6 & 8 \\
\hline 1. & Jansa & 3.58 & 11.25 & 5.00 \\
\hline 2. & BHU & 4.17 & 9.50 & 5.83 \\
\hline 3. & Pindra & 3.50 & 10.25 & 5.50 \\
\hline 4. & Leva & 4.17 & 9.83 & 4.75 \\
\hline 5. & Raipur & 4.75 & 8.08 & 5.75 \\
\hline 6. & Makdumpur & 4.08 & 8.58 & 5.58 \\
\hline 7. & Mohommadabad & 4.42 & 8.00 & 5.25 \\
\hline 8. & Chirrayyakot & 4.08 & 10.00 & 6.00 \\
\hline 9. & Rajepur & 4.67 & 9.25 & 4.92 \\
\hline 10. & Mohobbatpur & 4.58 & 9.25 & 4.67 \\
\hline 11. & Jamalpur & 4.25 & 8.50 & 5.17 \\
\hline 12. & Keshavpur & 4.92 & 10.17 & 6.25 \\
\hline 13. & Jafrabad & 4.00 & 10.17 & 5.17 \\
\hline 14. & Kandhiya & 3.92 & 7.08 & 4.33 \\
\hline 15. & Bhikharipur & 3.08 & 9.25 & 5.83 \\
\hline 16. & Ugapur & 4.33 & 8.17 & 6.83 \\
\hline 17. & Vindhyanchal & 4.42 & 10.92 & 5.25 \\
\hline 18. & Rajpur-1 & 3.67 & 9.92 & 4.67 \\
\hline 19. & Rajpur-2 & 3.83 & 10.58 & 5.50 \\
\hline 20. & Bharpura-1 & 4.33 & 10.00 & 4.75 \\
\hline 21. & Bharpura-2 & 4.33 & 9.42 & 5.00 \\
\hline 22. & Chunar & 3.50 & 10.50 & 4.58 \\
\hline 23. & Jamalpur & 4.50 & 10.00 & 5.08 \\
\hline 24. & Raibarely & 3.92 & 12.92 & 6.08 \\
\hline 25. & Rastamau & 4.25 & 11.08 & 5.00 \\
\hline 26. & Sidhona & 4.25 & 7.75 & 5.00 \\
\hline 27. & Kanpur-M & 4.17 & 7.42 & 5.50 \\
\hline 28. & Kanpur-C & 4.17 & 10.75 & 5.00 \\
\hline 29. & Nalanda & 4.17 & 10.92 & 5.08 \\
\hline 30. & Dumraon & 3.92 & 7.67 & 4.67 \\
\hline & & Isolate (I) & $\mathbf{p H}(\mathbf{p})$ & $\mathbf{I} \times \mathbf{p}$ \\
\hline SEn & $( \pm)$ & 0.17 & 0.56 & 0.311 \\
\hline CD & $0.01)$ & 0.50 & 0.15 & 0.87 \\
\hline $\mathrm{CV}$ & & 5.66 & & \\
\hline
\end{tabular}


Least rate of growth was observed in isolate Kandhiya $(7.08 \mathrm{~mm})$ which was found at par Kanpur-M (7.42mm) and Dumraon (7.67mm). At pH eight, Ugapur $(6.83 \mathrm{~mm})$ was found to have maximum rate of growth followed by Keshavpur $(6.25 \mathrm{~mm})$, Raibarely $(6.08 \mathrm{~mm})$, Chirrayyakot $(6.00 \mathrm{~mm})$, BHU $(5.83 \mathrm{~mm})$, Bhikharipur $(5.83 \mathrm{~mm})$ and Raipur $(5.75 \mathrm{~mm})$ which were found at par each other. Minimum rate of growth was observed in isolate Kandhiya $(4.33 \mathrm{~mm})$ followed by Chunar (4.58mm), Mohobbatpur (4.67mm), Rajpur-1 (4.67mm), Dumraon $(4.67 \mathrm{~mm})$, Leva $(4.75 \mathrm{~mm})$ and Bharpura-1 $(4.75 \mathrm{~mm})$.

Results presented above are corroborate with study conducted by Maheshwari et al., 2001 who reported optimum $\mathrm{pH}$ for the growth of the fungus Alternaria alternata was $\mathrm{pH} 6.5$ respectively. Study carried by Hubballi et al., (2010) on effect of hydrogen ion concentration on mycelial growth of Alternaria alternata causing leaf blight of Noni is also corroborant with the present study.

Results of their experiment indicated that the growth of Alternaria alternata was maximum in $\mathrm{pH}$ range of 6.00- 6.50. Kantwa et al., 2015 observed maximum mycelial growth and sporulation on potato dextrose agar at $\mathrm{pH}$ 6.5. The $\mathrm{pH} 7.0$ was found optimum for the growth and sporulation of Alternaria alternata (Zarger et al., 2015).

Mishra and Thawani (2016) concluded by their study that the best growth and sporulation of the fungus Alternaria alternata was observed at slightly acidic and neutral $\mathrm{pH}$ range. Relationship of $\mathrm{pH}$ to the mycelial growth of Alternaria alternata was determined at different $\mathrm{pH}$ levels viz. 4.0 to 8.0 at $25 \pm 1{ }^{\circ} \mathrm{C}$ for 7 days. Of all the eight $\mathrm{pH}$ levels, $\mathrm{pH} 6.5$ was found to be ideal and produced the maximum dry mycelial weight (Choudhary et al., 2017). Results are also in accordance with earlier reports of Gawai and Mangnalikar (2018) who reported that the $\mathrm{pH}$ 6.5 is optimum for the growth Alternaria alternata.

\section{References}

Barnett, H.L. and Bany, B.C. 1972. Illustrated genera of Imperfect fungi $3^{\text {rd }} \mathrm{Edn}$. Burgess Pub. Co. Mannesto. 149 pp.

Boiteux, L. and Reifschneider, F. 1994. Potato early blight caused by Alternaria alternata in Brazil. Plant Disease. 78: 101.

Droby, S., Dinoor, A., Prusky, D. and BarkaiGolan, R. 1984. Pathogenicity of Alternaria alternata on potato in Israel. Phytopathology. 74(5): 537-542.

Ellis, M. B. 1971. Dematiaceous hypomycetes, Commonwealth Mycological Institute, Kew, Surry. England. 608 p.

Ellis, M.B. and Gibson, I.A.S. 1975. Alternaria solani. No.475 in: Descriptions of pathogenic fungi and bacteria. Commonw. Mycol. Inst./Assoc. Appl. Biol., Kew, Surrey, England.

Eshel, D.; Ben-Arie, R. Dinoor, A. and Prusky, D. 2000. Resistance of Gibberellin-Treated Persimmon Fruit to Alternaria alternata Arises from the Reduced Ability of the Fungus to Produce Endo-1, 4-b-Glucanase Phytopathology. 90(11):1256-62

Gawai, D.U. and Mangnalikar, S.S. 2018. Effect of Temperature and $\mathrm{pH}$ on growth of Alternaria alternata, leaf spot pathogen of soyabean. Bioscience Discovery. 9(1): 162-165.

Gilman, C.J. 1975. Manual of soil fungi $3^{\text {rd }}$ edn. Oxford and IBH publishing Co., New Delhi. pp. 339-340.

Hubballi, M., Nakkeeran, S., Raguchander, T., Anand, T. and Samiyappan, R. 2010. Effect of environmental conditions on 
growth of Alternaria alternata causing leaf blight of noni. World Journal of Agricultural Sciences. 6(2):171-177.

Kantwa, S. L., Shekhawat, K. S., and Tetarwal, J. P. 2015. Studies on physiological parameters of Alternaria alternata (Fr) Keissler-the incitant of leaf blight of groundnut. International Journal of Plant Protection, 8(2):359363.

Maheshwari, S. K., Singh, D. V., and Singh, S. B. 2000. Effect of temperature and $\mathrm{pH}$ on growth and sporulation of Alternaria alternata causing Alternaria leaf spot of dolichos bean. Annals of Plant Protection Sciences. 8(1): 33-35.

Mishra, P. K., and Thawani, V. (2016). Characterization of Alternaria alternata isolated from Calotropis gigantea plant leaf. International Journal of Current Microbiology and Applied Sciences. 5: 459-466.

Pryor, B. M., and Michailides, T. J. 2002. Morphological, pathogenic, and molecular characterization of Alternaria isolates associated with Alternaria late blight of pistachio. Phytopathology. 92(4): 406-416.

Shahid, A., Iftikhar, S., Nawaz, K. Anwar, W., Ali, S. 2017. First report of Alternaria alternata causing Brown spot of potato in Pakistan. Journal of Plant Pathology, 99: 300-301.

Soleimani, M. and Kirk, W. 2012. Enhance resistance to Alternaria alternata causing potato brown leaf spot disease by using some plant defense inducers. Journal of Plant Protection Research. 52(1): 83-90.

Subramanian, C.V. 1971. Hyphomycetes. ICAR, New Delhi, pp. 815-818.

URL 4: www.eands.dacnet.nic.in accessed on $11 / 03 / 2018$

Van der Waals, J. E., Pitsi, B. E., Marais, C., and Wairuri, C. K. 2011. First report of Alternaria alternata causing leaf blight of potatoes in South Africa. Plant Disease. 100(4): 797-801

Zarger, S. A., Rizvi, G., and Parashar, R. 2015. Studies on leaf spot disease of mango and its management. International Journal of Pharma and Biosciences. 6(1): (B) $769-776$.

\section{How to cite this article:}

Shrishti Lingwal and Asha Sinha. 2018. Variability in Alternaria alternata Causing Potato Brown Spot under Different Hydrogen Ion Concentration. Int.J.Curr.Microbiol.App.Sci. 7(04): 961-968. doi: https://doi.org/10.20546/ijcmas.2018.704.102 